\title{
Twenty-One Years of Fruit Research at East Malling
}

$\mathrm{T}$ HE Fruit Research Station at East Malling, in the heart of the Kent fruit area, which was established in 1913, at the request, and with the active and continued assistance, of fruit growers, celebrates its coming-of-age at the annual meeting of its supporters on May 24. The occasion is being graced by the presence of His Royal Highness the Duke of York, who has consented to honour the Station by visiting its plantations and laboratories on that date, when the Institute's subscribing members, now numbering 1,000 , will have their annual opportunity of making a closer acquaintance with the results of the experimental work, special demonstrations of which will be staged.

A prime essential for the successful prosecution of research on fruit plants is continuity of policy. If more than fragmentary information is to be obtained, experiments must cover a reasonable proportion of the useful life of the subject, so that an investigation even of strawberries may last four or five seasons, whilst the full value of trials of tree fruits may not be obtained in less than twenty years.

Since 1913, in spite of the necessary restriction of its activities during the War years, the Station, by adherence to a clear-cut programme of longdistance research in the field and in the laboratory, has obtained results of fundamental importance to fruit growers. The annual total of 2,000 interested inquirers who visit the Station is an indication of the confidence placed in its work by the industry, which recognises that the best fruit must be grown before the best marketing methods can be applied.

Important contributions have been made to the practice of the culture of small fruits such as black currants and raspberries, first by systematic botanical studies of varieties, which made possible accurate identification and consequently the accumulation and maintenance of races and strains true to type. Only when this had been effected was it possible to begin field trials to determine the cropping capacity, manurial requirements, disease resistance and market value of the multitude of varieties available in commerce. Such investigations, coupled with the elaboration of methods of control of pests and diseases, have been the main factor in lifting black currant culture from a haphazard gamble to its present condition of an organised system of operations which can be undertaken with a reasonable certainty of success.

Similar methods, linked up with the evolution of a scheme of nursery hygiene, have been applied to raspberry growing, and a large measure of success has already been obtained, whilst problems of the propagation and control of diseases and pests of the strawberry, loganberry and blackberry are under investigation.

Fruits such as apples, pears, plums and cherries, the trees of which are budded or grafted on root systems other than their own, present problems similar to those of the small fruits; but, in addition, further complications are introduced by the presence of the foreign root system. The first step was the collection of examples of these rootstocks from a wide range of commercial sources, and after meticulous botanical examination it was possible to construct a very necessary system of classification for identification purposes and to avoid future confusion. The next stage was the multiplication of the different rootstock types, and for this purpose vegetative methods were resorted to in order to preserve to each its own genetic constitution. This process alone involved a prolonged intensive investigation, since many varieties did not propagate easily and special methods had to be evolved to apply to different cases. Trials have been made with hardwood and softwood cuttings, root cuttings, layers and stools, and thus was found the most suitable method for each variety. The next process was the raising of series of trees of commercial scion varieties budded or grafted on each type of rootstock, and these were then planted out, grown under a recognised commercial system of culture, and intensive records of individual tree performance were taken over several years. The records include annual measurements of the total length of new shoots, the girth of the trunk, the height and spread of the branches, leaf area, the number of blossom trusses formed and the number, size, colour and quality of fruits.

In parallel with field trials of this type, experiments have been carried out in which similar trees are subjected to different degrees of winter stem pruning, the effect on subsequent performance being measured by a series of routine records as in the rootstock trials.

Manurial investigations have been conducted, both in the field and in pot culture, and valuable information relative to this subject has also been obtained by work on the spatial distribution and time of growth of roots. A number of trees up to ten years old on different soils have been excavated piecemeal and then reconstructed, giving a picture of the spread and depth of the roots to which manurial substances have to be supplied. The time and rate of root growth are determined by direct measurement of growing roots through glass windows in the sides of underground observation posts.

These and other converging lines of research have now made it possible to classify the rootstocks on the basis of the influence which they exert on the scion; and the trees growing in the plantations of the institute, each coupled with its own particular record of past performance, demonstrate the fundamental importance of using standardised rootstocks, chosen with full regard for their potentialities, which are now known with considerable accuracy. 
It has, of course, long been known vaguely that the rootstock has some influence on the performance of a tree but the accumulated results of the Station's experiments have shown just what this influence may achieve and how advantage may be taken of it, though it is not yet clear what physiological and chemical mechanism is involved in the translation of rootstock potentialities into scion performance. It is, however, now certain that choice of rootstock may mean the difference between the economic success and failure of a plantation, since such factors as the vigour and disease-resistance of the tree, the age at which fruit-production begins, the amount of crop and the size, colour and quality of the fruit may all be affected by the rootstock.

Some control of these factors may, of course, be achieved by such cultural treatments as pruning and manuring, but since tree fruit plantations are planned in relation to a future of $30-50$ years, the importance of obtaining control of the trees by selecting at the outset the correct rootstock in relation to its purpose need scarcely be emphasised. The extent of this control is such that it is now possible by rootstock selection to choose in advance whether a tree shall become a dwarf bush for the garden or a large 'standard' with a spread of $40 \mathrm{ft}$., and in fact to produce at will trees suitable each for its particular purpose.

The natural corollary of these investigations was not only to make them known to the fruit. growing industry but also to make available the material with the aid of which the principles could be applied. Consequently in order to ensure that growers and nurserymen shall be able to procure in quantity suitable rootstocks and desirable and healthy varieties of small fruits all true to type, the Station has established a considerable acreage of nurseries where material is raised and distributed through commercial sources. The number of plants thus made available now amounts to 250,000 annually. The area now under experiments amounts to 130 acres and in the course of the investigations problems have arisen which have necessitated co-operation of pomologists, physiologists, mycologists, bacteriologists, entomologists, statisticians and chemists; their publications appear in the Station's Annual Reports and in biological journals, chiefly the Journal of Pomology and Horticultural Science.

The Imperial Bureau of Fruit Production, founded in 1929, is housed at the Station and acts as a clearing house of information concerning research on fruit plants, which is made available through Horticultural Abstracts.

\section{Canadian Water Power Developments during 1933}

\section{By Dr. Brysson Cunningham}

$\mathrm{T}$ $\mathrm{HE}$ recent issue by the Dominion Water Power and Hydrometric Bureau of the Canadian Department of the Interior of two reports $^{1}$ relating to hydro-electric developments during the year 1933 enables a fresh survey to be made of the remarkable progress which continues to be achieved in the Dominion in the exploitation of its natural water power resources.

It was scarcely to be expected that the rate of development which, from 1924 until the end of 1932, was fairly constant at the high figure of nearly 440,000 additional horse power per annum, could be maintained during the present period of economic depression. In the circumstances, it is satisfactory to record that the net increase during 1933 was no less than 270,210 horse power, bringing (with a previously untabled item of 16,600 horse power in 1932) the total development at the beginning of this year up to $7,332,070$. It is conservatively estimated that this represents a capital investment of $1,675,000,000$ dollars and that it is capable of effecting a saving of about $36,000,000$ tons of coal per annum. The actual saving for the year 1933 is computed at $14,775,000$ tons. As projects require several years to materialise, the annual increment of power is, of course, mainly due to installations the inception of which dates back a corresponding period. During 1934 and thereafter, there will be further increments on the completion of undertakings now under way, but, from the point of view of the maintenance of the rate of progress, it is significant and unfortunate that no undertakings of magnitude were initiated during 1933.

The distribution of the present realised total of $7,332,070$ horse power among the various provinces of the Dominion is shown in the accompanying

AVAILABLE AND DEVELOPED WATER POWER IN CANADA, January 1, 1934.

\begin{tabular}{|c|c|c|c|c|}
\hline \multirow{2}{*}{\multicolumn{2}{|c|}{ Province }} & \multicolumn{2}{|c|}{$\begin{array}{l}\text { Available } 24 \text {-hour power } \\
\text { at } 80 \text { per cent Efficiency }\end{array}$} & \multirow{2}{*}{$\begin{array}{c}\text { Turbine } \\
\text { Installation } \\
\text { (h.p.) }\end{array}$} \\
\hline & & $\begin{array}{l}\text { At Ordinary } \\
\text { Min. Flow } \\
\text { (h.p.) }\end{array}$ & $\begin{array}{l}\text { At Ordinary } \\
\text { Six Months' } \\
\text { Flow (h.p.) }\end{array}$ & \\
\hline \multicolumn{2}{|c|}{ British Columbia .. } & $1,931,000$ & $5,103,500$ & 717,602 \\
\hline Alberta & & 390,000 & $1,049,500$ & 71,597 \\
\hline Saskatchewan & & 542,000 & $1,082,000$ & 42,035 \\
\hline Manitoba .. & .. & $3,309,000$ & $5,344,500$ & 390,925 \\
\hline Ontario $\quad .$. & $\because$ & $5,330,000$ & $6,940,000$ & $2,355,105$ \\
\hline Quebec $\quad .$. & & $8,459,000$ & $13,064,000$ & $3,493,320$ \\
\hline New Brunswick & & 68,600 & 169,100 & 133,681 \\
\hline Nova Scotia & & 20,800 & 128,300 & 112,167 \\
\hline Prince Edward Isle & & 3,000 & 5,300 & 2,439 \\
\hline Yukon and Northw & west Terr. & 294,000 & 731,000 & 13,199 \\
\hline Total & $\ldots$ & $20,347,400$ & $33,617,200$ & $7,332,070$ \\
\hline
\end{tabular}

table, which also exhibits a statement of the estimated total power available. It would not be correct, however, to deduct the realised horse power in column 4 from either of the totals of available power in columns 2 and 3 , for the purpose of arriving at the balance still awaiting development, because experience in the matter of turbine 